\title{
Optimized digestion methods: organic phosphorus sequential extraction, total phosphorus, and nitrogen simultaneous determination in sediments
}

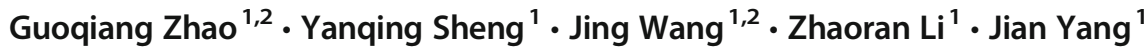

Received: 4 October 2017 / Accepted: 16 February 2018 / Published online: 27 February 2018

(C) Springer-Verlag GmbH Germany, part of Springer Nature 2018

\begin{abstract}
Purpose The organic phosphorus (OP) that is found in sediments influences the water quality of the overlying water. Accurate methods for OP extraction are important to identify phosphorus fractions in the sediments. We optimized the following: (1) the $\mathrm{pH}$ range of solutions after digestion; (2) the amounts of TP, $\mathrm{H}_{2} \mathrm{SO}_{4}$, and $\mathrm{K}_{2} \mathrm{~S}_{2} \mathrm{O}_{8}$ in the digestion; and (3) the digestion efficiency between acid $\mathrm{K}_{2} \mathrm{~S}_{2} \mathrm{O}_{8}$ and alkaline $\mathrm{K}_{2} \mathrm{~S}_{2} \mathrm{O}_{8}$ in total phosphorus (TP) and total nitrogen (TN) measurements. Moreover, we explained the related experimental phenomena and the results with an in-depth mechanism.

Materials and methods Sediments samples were taken from three locations (Yellow Sea, Jiehe River, and Jiaolai River, China). Each sample was analyzed to optimize sequential OP extraction based on the Ivanoff method.

Results and discussion We focused on the digestion step and digestion efficiency between acidic $\mathrm{K}_{2} \mathrm{~S}_{2} \mathrm{O}_{8}$ and alkaline $\mathrm{K}_{2} \mathrm{~S}_{2} \mathrm{O}_{8}$, total phosphorus (TP), and total nitrogen (TN) measurements. The results indicate that the optimal $\mathrm{pH}$ range of solutions after digestion is from 3 to 5.5. The TP digestion efficiency in combination with $\mathrm{H}_{2} \mathrm{SO}_{4}+\mathrm{K}_{2} \mathrm{~S}_{2} \mathrm{O}_{8}$ (acid) is, on average, $8 \%$ higher than that of $\mathrm{NaOH}+\mathrm{K}_{2} \mathrm{~S}_{2} \mathrm{O}_{8}$ (alkaline). However, the results for TN suggest the opposite. Optimal amounts of TP, $\mathrm{H}_{2} \mathrm{SO}_{4}$, and $\mathrm{K}_{2} \mathrm{~S}_{2} \mathrm{O}_{8}$ for digestion were also clearly determined.

Conclusions The $\mathrm{pH}$ of solutions after digestion affects the color development necessary for effective phosphorus (P) determination. The TP and TN could be determined simultaneously using the alkaline $\mathrm{K}_{2} \mathrm{~S}_{2} \mathrm{O}_{8}$ digestion system under the experimental conditions. Finally, the optimal orthogonal combinations and mass ratios of $\mathrm{P}_{2} \mathrm{~K}_{2} \mathrm{~S}_{2} \mathrm{O}_{8}$, and $\mathrm{H}_{2} \mathrm{SO}_{4}$, respectively, were determined to be $\sim 1.5 \times 10^{-5}: 1: 8\left(\mathrm{NaHCO}_{3}, 16 \mathrm{~h}\right), \sim 5.6 \times 10^{-5}: 1: 3(\mathrm{HCl}, 3 \mathrm{~h}), \sim 1.6 \times 10^{-5}: 1: 5(\mathrm{NaOH}, 16 \mathrm{~h})$, and $\sim 1.4 \times 10^{-5}: 1: 8$ $(\mathrm{NaOH}, 16 \mathrm{~h}, \mathrm{pH}=0.2)$. We improved the accuracy and precision of the Ivanoff method using an optimized sequential extraction method.
\end{abstract}

Keywords Organic phosphorus $\cdot$ Sequential extraction method $\cdot$ Simultaneous determination $\cdot$ Total phosphorus $\cdot$ Total nitrogen

\section{Introduction}

Responsible editor: Shiming Ding

Electronic supplementary material The online version of this article (https://doi.org/10.1007/s11368-018-1959-6) contains supplementary material, which is available to authorized users.

Yanqing Sheng

yqsheng@yic.ac.cn

1 Research Center for Coastal Environment Engineering Technology of Shandong Province, Yantai Institute of Coastal Zone Research, Chinese Academy of Sciences, Yantai, China

2 University of Chinese Academy of Sciences, Beijing, China
Phosphorus $(\mathrm{P})$ is an important and limiting nutrient for primary production in aquatic environments (Kaiserli et al. 2002; Ahlgren et al. 2005; Fowdar et al. 2017). However, excessive $P$ from industrial and agricultural emissions has already caused some serious environmental pollution problems (Smi 2000). Phosphorus pollution can trigger eutrophication, biodiversity loss, and oxygen depletion in water (Chowdhury et al. 2017). According to figures from the US EPA, it costs communities approximately US $\$ 2.2$ billion every year to remedy drinking water and recreational water and to protect endangered species that are threatened by algal blooms (Dodds et al. 2009). 
Sediments that adsorb large amounts of $\mathrm{P}$ are thought to be an important source of $\mathrm{P}$ for overlying water (Monbet et al. 2007; Hu et al. 2011). The P in sediments can be divided into inorganic P (IP) and organic P (OP), of which OP accounts for $12-42 \%$ of the total P (TP) (Ding et al. 2010). Studies have shown that considerable quantities of released $\mathrm{P}$ are from OP found in sediments (Suzumura and Kamatani 1995; Slomp et al. 2002). Under certain conditions, the decomposition of OP in sediments becomes an important source of soluble reactive P (SRP) in water (Bostrom et al. 1989). Similar to the sequential extraction of IP (Hieltjes and Lijklema 1980), OP can also be divided into many fractions (Zhu et al. 2013). However, the fractions and distributions of OP in sediments are poorly understood because there are currently no effective fractionation and characterization approaches (Zhang et al. 2008). Bowman and Cole (1978) developed a chemical fractionation method for OP in soil, and they divided OP into four distinct fractions using a sequential extraction method: labile OP, moderately labile OP, moderately resistant OP, and highly resistant OP. However, there are some problems associated with this method, such as the incomplete removal of high concentrations of phytate in most soils and sediments (Oluyedun et al. 1991; Golterman et al. 1998; Turner et al. 2002). Their fractionation method has been further improved by Tiessen et al. (1983), Sharpley and Smith (1985), and Ivanoff et al. (1998). For example, Ivanoff et al. (1998) developed a sequential extraction method for OP in soils. The OP recovery was improved by using an additional step to determine residual OP and biomass OP. Currently, there are no unanimously accepted fractionation procedures for analyzing OP in sediments (Li et al. 2013), and the sequential extraction procedure is still being improved and modified to estimate the fractionation of $\mathrm{P}$ in soil or sediment (Waterlot 2018). Although it is a classical method, there are still some problems with the Ivanoff method. For example, the proportions of OP, $\mathrm{H}_{2} \mathrm{SO}_{4}$, and persulfate in the digestion are uncertain. In addition, the concentration of $\mathrm{P}$ during extraction and digestion are determined without $\mathrm{pH}$ adjustments. Furthermore, a $\mathrm{pH}$ range for the effective measurement of TP by the ascorbic acidmolybdenum blue method is not obtained (Murphy and Riley 1962; Tiessen et al. 1983). The previous problems could affect the accuracy of OP determination. Therefore, it is essential to optimize the fractionation method of OP in sediments. Additionally, during the determination process, OP maybe converted to IP under the $\mathrm{K}_{2} \mathrm{~S}_{2} \mathrm{O}_{8}$ digestion condition. There is a similar scenario for TN measurement where different forms of $\mathrm{N}$ change to nitrate nitrogen $\left(\mathrm{NO}_{3}{ }^{-}-\mathrm{N}\right)$ when $\mathrm{TN}$ is affected by $\mathrm{K}_{2} \mathrm{~S}_{2} \mathrm{O}_{8}$. Therefore, the feasibility of determining TN using a TP digestion system is worth studying. There have been studies of the simultaneous determination of TP and TN using either an alkaline or acid peroxydisulfate, but those authors did not give an in-depth description of the mechanisms or phenomena (Worsfold et al. 2005).
The objectives of this study are to (1) investigate and optimize the $\mathrm{pH}$ range of the digestion solution for TP measurement by the phosphor-molybdate colorimetric method; (2) identify the digestion efficiency of TP and TN using the two digestion systems $\mathrm{H}_{2} \mathrm{SO}_{4}+\mathrm{K}_{2} \mathrm{~S}_{2} \mathrm{O}_{8}$ and $\mathrm{NaOH}+\mathrm{K}_{2} \mathrm{~S}_{2} \mathrm{O}_{8}$; (3) investigate the feasibility of determining $\mathrm{TP}$ and $\mathrm{TN}$ using the same digestion system; and (4) investigate the relationship between the TP digestion efficiency and the concentration of $\mathrm{P}$, as well as dosages of $\mathrm{H}_{2} \mathrm{SO}_{4}$ and $\mathrm{K}_{2} \mathrm{~S}_{2} \mathrm{O}_{8}$. Moreover, the aims of this study are to explain the related experimental phenomena and results with an in-depth mechanism and to improve the accuracy and precision of the classical Ivanoff OP sequential extraction method by using an optimized method.

\section{Materials and methods}

\subsection{Study site and sampling}

The Jiehe River and Jiaolai River are located in the northwest of the Shandong Peninsula, and they flow northwest into the Laizhou Bay of the Bohai Sea, China (Fig. 1). Both rivers have been heavily contaminated. Pollution in the Jiehe River is mainly caused by local mining and smelting activities (Bi and Zhao 2017). Pollution in the Jiaolai River is mainly caused by upstream industrial effluent (Cai et al. 2015; Li et al. 2016). Sediment samples were collected using a Van Veen grab sampler (Fig. 1). Composite surface sediment samples were stored in sealed plastic bags in an adiabatic box and then frozen at $-24^{\circ} \mathrm{C}$ until the analysis was performed. The samples were freeze dried and sieved (100 mesh) prior to the analysis.

\subsection{Measurements}

The TP was measured by calcination in a muffle furnace $\left(550{ }^{\circ} \mathrm{C}\right)$ and was then extracted using a solution of $1 \mathrm{~mol} \mathrm{~L}^{-1} \mathrm{HCl}$. Total IP (TIP) was measured by extraction with $1 \mathrm{~mol} \mathrm{~L}^{-1} \mathrm{HCl}(16 \mathrm{~h})$ without calcination. The difference between TP and TIP was total OP (TOP) (Aspila et al. 1976). The three solid-phase fractions of OP determination (readily labile OP, moderately labile OP, and nonlabile OP) in the sediment samples were based on the Ivanoff method (Ivanoff et al. 1998).

1. Readily labile OP: A total of 1.0-g sediment samples that had been sieved through a 100 -mesh sieve was initially extracted with $50 \mathrm{~mL}$ of $0.5 \mathrm{~mol} \mathrm{~L}^{-1} \mathrm{NaHCO}_{3}$ at $\mathrm{pH} 8.5$ for $16 \mathrm{~h}$ and was then centrifuged at $4000 \mathrm{~g}$ for $15 \mathrm{~min}$. After the centrifugation, the extract was collected to determine both IP and TP. The difference between TP and IP was readily labile OP. 


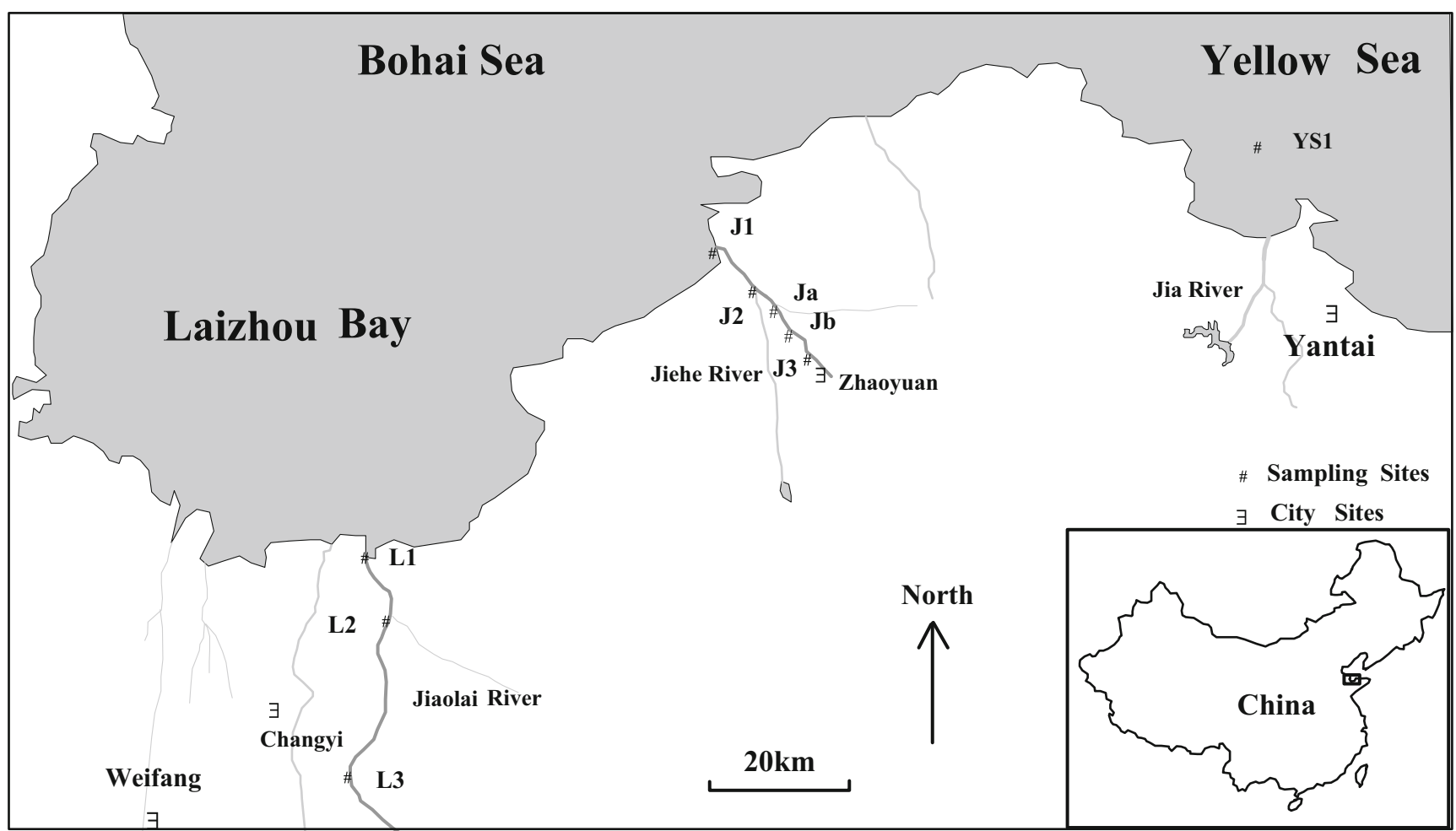

Fig. 1 The location of the sampling sites. One is located in the north Yellow Sea (YS1), three of them are in the Jiaolai River (L1, L2, and L3), and five of them are in the Jiehe River (J1, J2, J3, Ja, and Jb)

2. Moderately labile OP: The residue from the $\mathrm{NaHCO}_{3}$ extraction was extracted with $50 \mathrm{~mL}$ of $1.0 \mathrm{~mol} \mathrm{~L}{ }^{-1} \mathrm{HCl}$ for $3 \mathrm{~h}$. The residue from the $\mathrm{HCl}$ extraction was rinsed with deionized water and then extracted using $50 \mathrm{~mL}$ of $0.5 \mathrm{~mol} \mathrm{~L}^{-1} \mathrm{NaOH}$ for $16 \mathrm{~h}$. The $\mathrm{NaOH}$ extract was acidified to $\mathrm{pH} 0.2$ with concentrated $\mathrm{HCl}$ to separate the nonlabile fraction (humic acid-P) from the moderately labile fraction (fulvic acid-P). All extracts were centrifuged and analyzed for TP and IP. The HCl-OP and fulvic acid-OP were moderately labile OP.

3. Nonlabile-OP: The rinsed residue from the $\mathrm{NaOH}$ extraction was ashed at $550{ }^{\circ} \mathrm{C}$ for $1 \mathrm{~h}$ and then extracted with $1 \mathrm{~mol} \mathrm{~L}^{-1} \mathrm{H}_{2} \mathrm{SO}_{4}$ for $24 \mathrm{~h}$. After centrifugation, the extract was analyzed for TP. The sum of $\mathrm{H}_{2} \mathrm{SO}_{4}$-TP and humic acid-OP was nonlabile-OP.

Total extracted OP is the sum of the three solid-phase fractions of OP described previously. The $\mathrm{P}$ concentration in all extracts was determined according to the molybdenum blue method (Murphy and Riley 1962). Total organic carbon (TOC) and TN in the sediment samples were analyzed using a total organic carbon analyzer (TOC-VCPH, Shimadzu, Japan). The TN in all solutions was measured using a spectrophotometric method where all forms of nitrogen were oxidized to $\mathrm{NO}_{3}{ }^{-} \mathrm{N}$, and the final concentration of $\mathrm{NO}_{3}{ }^{-}-\mathrm{N}$ was used as TN (Chinese EPA 2002). The concentrations of urea (organic $\mathrm{N}$ ) in all samples were measured using a spectrophotometry method that is based on the reaction of diacetylmonoxime and urea in an acidic solution (Zhao et al. 2011). The nitrite determination method was based on the reactions of sulfonamides with nitrite under acidic conditions, followed by coupling with $N$-(1-naphtyl) ethylenediamine dihydrochloride (NED) (Pandurangappa and Venkataramanappa 2007). Sediment grain sizes were measured using a laser particle size analyzer (Marlvern Mastersizer 2000F, Malvern, UK). Triplicates were analyzed for all samples, and the results are expressed as their average. The relative standard deviation (RSD) of the measurements is $\leq 5 \%$.

\subsection{The $\mathrm{pH}$ gradient experiments of digestion solutions}

The eight parallel solutions containing $\mathrm{OP}(\mathrm{P}<30 \mu \mathrm{g})$ derived from sediment extraction were added to eight $50-\mathrm{mL}$ colorimetric tubes. The eight parallel solutions were digested for TP determination (Bowman 1989). The parallel digestion solutions were spiked with $2.5 \mathrm{~mol} \mathrm{~L}^{-1} \mathrm{NaOH}$ or $2.5 \mathrm{~mol} \mathrm{~L}^{-1}$ $\mathrm{H}_{2} \mathrm{SO}_{4}$ to adjust $\mathrm{pH}$ to approximately $1,2,3,5,7,9,11$, and 13 after digestion. The previous mixtures were diluted by adding Milli-Q water to the 50-mLcomparison tubes for $\mathrm{P}$ determination. The reported results are the average values of three parallel experiments. 


\subsection{The TP digestion by systems of $\mathrm{H}_{2} \mathrm{SO}_{4}+\mathrm{K}_{2} \mathrm{~S}_{2} \mathrm{O}_{8}$ and $\mathrm{NaOH}+\mathrm{K}_{2} \mathrm{~S}_{2} \mathrm{O}_{8}$}

To compare the digestion efficiency of TP using $\mathrm{H}_{2} \mathrm{SO}_{4}+$ $\mathrm{K}_{2} \mathrm{~S}_{2} \mathrm{O}_{8}$ and $\mathrm{NaOH}+\mathrm{K}_{2} \mathrm{~S}_{2} \mathrm{O}_{8}, 12$ parallel solutions containing OP (Sect. 2.3) of accurately measured aliquots $(\mathrm{P}<30 \mu \mathrm{g})$ were added into 12 colorimetric tubes $(50 \mathrm{~mL})$. The tubes were divided into three series: (1) tubes A-E were spiked with different amounts of $2.5 \mathrm{~mol} \mathrm{~L}^{-1} \mathrm{NaOH}(0.5,1,2,4$, and $6 \mathrm{~mL}$ ) and $3 \mathrm{~mL}$ of $5 \% \mathrm{~K}_{2} \mathrm{~S}_{2} \mathrm{O}_{8}$ (wt\%); (2) tube $\mathrm{F}$ was not spiked with $5 \% \mathrm{~K}_{2} \mathrm{~S}_{2} \mathrm{O}_{8}(\mathrm{wt} \%), \mathrm{H}_{2} \mathrm{SO}_{4}$, or $\mathrm{NaOH}$ addition and tube $\mathrm{G}$ was spiked with $3 \mathrm{~mL}$ of $5 \% \mathrm{~K}_{2} \mathrm{~S}_{2} \mathrm{O}_{8}$ (wt $\%$ ) without the $\mathrm{H}_{2} \mathrm{SO}_{4}$ or $\mathrm{NaOH}$ addition. Group $\mathrm{G}$ is the standard method published by the Chinese EPA (2002); (3) tubes $\mathrm{H}-\mathrm{L}$ were spiked with different amounts of $2.5 \mathrm{~mol} \mathrm{~L}^{-1} \mathrm{H}_{2} \mathrm{SO}_{4}(0.5,1$, 2,4 , and $6 \mathrm{~mL}$ ) and $3 \mathrm{~mL}$ of $5 \% \mathrm{~K}_{2} \mathrm{~S}_{2} \mathrm{O}_{8}(\mathrm{wt} \%$ ). Milli-Q water was added to these 12 tubes until they were filled to the $25-\mathrm{mL}$ tick mark for digestion (Halstead et al. 1999). The resulting concentration of TP was used to represent digestion efficiency. After digestion, the $\mathrm{pH}$ values of the 12 parallel digestion solutions were adjusted to the effective colorimetric $\mathrm{pH}$ range by adding 1 or $6 \mathrm{~mol} \mathrm{~L}^{-1} \mathrm{NaOH}$ and 1 or $6 \mathrm{~mol} \mathrm{~L}^{-1} \mathrm{H}_{2} \mathrm{SO}_{4}$, and then the tubes were diluted by Milli-Q water to the $50-\mathrm{mL}$ tick mark for the determination of $\mathrm{P}$.

\subsection{TN digestion by $\mathrm{H}_{2} \mathrm{SO}_{4}+\mathrm{K}_{2} \mathrm{~S}_{2} \mathrm{O}_{8}$ and $\mathrm{NaOH}+$ $\mathrm{K}_{2} \mathrm{~S}_{2} \mathrm{O}_{8}$}

Generally, the digestion system of $\mathrm{NaOH}+\mathrm{K}_{2} \mathrm{~S}_{2} \mathrm{O}_{8}$ is used for the determination of $\mathrm{TN}$ in water because the digestion efficiency can be promoted by the alkalinity associated with $\mathrm{K}_{2} \mathrm{~S}_{2} \mathrm{O}_{8}$ (Halstead et al. 1999). To investigate whether the digestion system of $\mathrm{H}_{2} \mathrm{SO}_{4}+\mathrm{K}_{2} \mathrm{~S}_{2} \mathrm{O}_{8}$ can be simultaneously applied to the digestion and determination of TN and TP, an experiment that compared the digestion efficiency of TN was performed.

The standard artificial solution containing $5 \mathrm{mg} \mathrm{L}^{-1}$ organic nitrogen, $5 \mathrm{mg} \mathrm{L}^{-1} \mathrm{NH}_{3}-\mathrm{N}$, and $5 \mathrm{mg} \mathrm{L}^{-1} \mathrm{NO}_{x}-\mathrm{N}$ was from analytically pure urea $\left(\mathrm{CO}\left(\mathrm{NH}_{2}\right)_{2}\right), \mathrm{NH}_{4} \mathrm{Cl}$, and $\mathrm{KNO}_{3}$. In natural water, urea is a common type of organic nitrogen and a significant part of the nitrogen from agricultural fertilizer and animal metabolism sources. It is also common in the laboratory. Consequently, urea was selected to represent organic nitrogen. Then, the standard $\mathrm{N}$ solutions $(2 \mathrm{~mL})$ were added into 12 colorimetric tubes $(25 \mathrm{~mL})$. The tubes were divided into three series: (1) tubes $1-5$ were spiked with $5 \mathrm{~mL}$ of different concentrations $\left(0.025,0.125,0.25,0.375\right.$, and $\left.0.5 \mathrm{~mol} \mathrm{~L}^{-1}\right)$ of $\mathrm{NaOH}$ solutions containing $4 \% \mathrm{~K}_{2} \mathrm{~S}_{2} \mathrm{O}_{8}$ (wt\%), (2) tube 6 was a blank group that did not contain $\mathrm{H}_{2} \mathrm{SO}_{4}$ or $\mathrm{NaOH}$ but contained $4 \% \mathrm{~K}_{2} \mathrm{~S}_{2} \mathrm{O}_{8}$ (wt $\%$ ), tube 7 was spiked with $4 \%$ alkaline $\mathrm{K}_{2} \mathrm{~S}_{2} \mathrm{O}_{8}$ (wt $\%$ ) and was analyzed with a standard oxidation digestion-UV spectrophotometry method for TN determination as published by the Chinese EPA (Zhou et al. 2012), and (3) tubes $8-12$ were spiked with $5 \mathrm{~mL}$ of different concentrations $\left(0.025,0.125,0.25,0.375\right.$, and $\left.0.5 \mathrm{~mol} \mathrm{~L}^{-1}\right)$ of $\mathrm{H}_{2} \mathrm{SO}_{4}$ solutions that contained $4 \% \mathrm{~K}_{2} \mathrm{~S}_{2} \mathrm{O}_{8}$ (wt $\%$ ). Milli-Q water was added to the 12 tubes until the 10 -mL tick mark for TN digestion (Halstead et al. 1999). Then, $1 \mathrm{~mL}$ of $\mathrm{HCl}(1+9)$ was added and diluted by Milli-Q water to the $25-\mathrm{mL}$ tick mark for TN determination after digestion.

\subsection{Orthogonal experiment of TP digestion efficiency}

To investigate the optimal conditions of TP digestion (where the TP value was regarded as an index), an orthogonal experiment of three factors at four levels was designed using the SPSS 19.0 software (SPSS, IBM Statistics 19.0 edition, USA) (Table 1).

\section{Results and discussion}

\subsection{Sediment characteristics}

The chemical components and fractions of $\mathrm{P}$ of the sediment samples are shown in Table 2. The concentrations of TP in the sediments range from 297 to $2797 \mathrm{mg} \mathrm{kg}^{-1}$. The concentration of IP dominates the $\mathrm{P}$ fraction, ranging from 271 to $1197 \mathrm{mg} \mathrm{kg}^{-1}$ (60-91.2\% of the TP). Additionally, OP content ranges from 26 to $380 \mathrm{mg} \mathrm{kg}^{-1}$, accounting for $8.8-40 \%$ of the TP. Concentrations of TOC and TN in sediments range from 0.11 to 2.3 and 0.04 to 0.36 (wt\%), respectively.

The Jiaolai River is a freshwater deficient river. Its water volume is mainly dependent on the influx from marine environments. As a consequence, marine silt and sand have been deposited at the sediment-water interface in the river. Therefore, sediments that are close to the estuary are dominated by larger particles in the Jiaolai River than the Jiehe River. However, the Jiehe River is a normal freshwater river that flows into the sea. There is more clay in Jiehe River sediments (Fig. 2). These findings suggest that the rivers have different grain size distributions, dependent on local geology. Additionally, their grain size distributions could influence distribution of pollutants (Jafarabadi et al. 2017). As pollutants accumulate more easily in small particles, a higher content of fine particulate matter in the sediment leads to a higher

Table 1 Design of orthogonal experiment

\begin{tabular}{llll}
\hline Levels & $\mathrm{A}$ & $\mathrm{B}$ & $\mathrm{C}$ \\
& $\mathrm{P}$ extracting solution $(\mathrm{mL})^{\mathrm{a}}$ & $\mathrm{H}_{2} \mathrm{SO}_{4}(\mathrm{~mL})$ & $\mathrm{K}_{2} \mathrm{~S}_{2} \mathrm{O}_{8}(\mathrm{~mL})$ \\
\hline 1 & 1 & 1 & 1 \\
2 & 2 & 2 & 2 \\
3 & 3 & 3 & 3 \\
4 & 5 & 5 & 5 \\
\hline
\end{tabular}

${ }^{\mathrm{a}}$ The moderately labile OP extracting solution $\left(1 \mathrm{~mol} \mathrm{~L}^{-1} \mathrm{HCl}, 3 \mathrm{~h}\right)$ was $1,2,3$, and 4 
Table 2 General chemical characteristics of the studied sediments

\begin{tabular}{|c|c|c|c|c|c|c|c|c|c|}
\hline Parameters & YS1 & L1 & $\mathrm{L} 2$ & L3 & $\mathrm{J} 1$ & $\mathrm{~J} 2$ & $\mathrm{~J} 3$ & $\mathrm{Ja}$ & $\mathrm{Jb}$ \\
\hline $\mathrm{TP}\left(\mathrm{mg} \mathrm{kg}^{-1}\right)$ & 533 & 409 & 297 & 695 & 539 & 715 & 677 & 1197 & 2797 \\
\hline IP $\left(\mathrm{mg} \mathrm{kg}^{-1}\right)$ & 441 & 361 & 271 & 445 & 429 & 630 & 488 & 1007 & 2417 \\
\hline OP $\left(\mathrm{mg} \mathrm{kg}^{-1}\right)^{\mathrm{b}}$ & $92(17.3)$ & 48 (11.7) & $26(8.8)$ & $250(40)$ & $110(20.4)$ & 85 (11.9) & 189 (27.9) & $190(15.9)$ & $380(13.6)$ \\
\hline TOC (\%) & 0.217 & 0.140 & 0.110 & 1.975 & 0.933 & 0.289 & 0.524 & 0.656 & 2.302 \\
\hline $\mathrm{TN}(\%)$ & 0.063 & 0.049 & 0.044 & 0.314 & 0.209 & 0.073 & 0.085 & 0.111 & 0.363 \\
\hline
\end{tabular}

${ }^{\mathrm{b}}$ Values in the parentheses are the percentage of TP in sediments (\%)

likelihood that more pollutants (such as TP, IP, OP, TN, and TOC) will be in a river (Fig. 2).

In the present study, the characteristics, origins, and pollution degrees of these sediment samples are different, which is a better representation in order to verify the reliability of the optimized OP sequential extraction method.

\subsection{The optimal pH range of a solution after digestion for TP determination}

The relationship between TP concentrations and solution $\mathrm{pH}$ is shown in Fig. 3. Triplicates were analyzed, and the average values are expressed in the results. Figure 3 shows that measured TP concentrations are low (close to zero) when the $\mathrm{pH}$ is lower than 2 or higher than 12 . Generally, the redox activity of ascorbic acid depends on $\mathrm{pH}$, so molybdenum phosphates could be reduced by ascorbic acid under strongly acidic conditions (Snehalatha et al. 1997; Mowry and Ogren 1999). Additionally, ascorbic acid is more likely to be oxidized under alkaline conditions than acidic conditions (Hou et al. 2017). Therefore, the ascorbic acid has possibly been oxidized because the $\mathrm{pH}$ is higher than 12 . In addition, TP is still not strictly consistent with the digestion solution $\mathrm{pH}$ values $(2-$ 12). As shown in Fig. 3, the experiment reveals that the

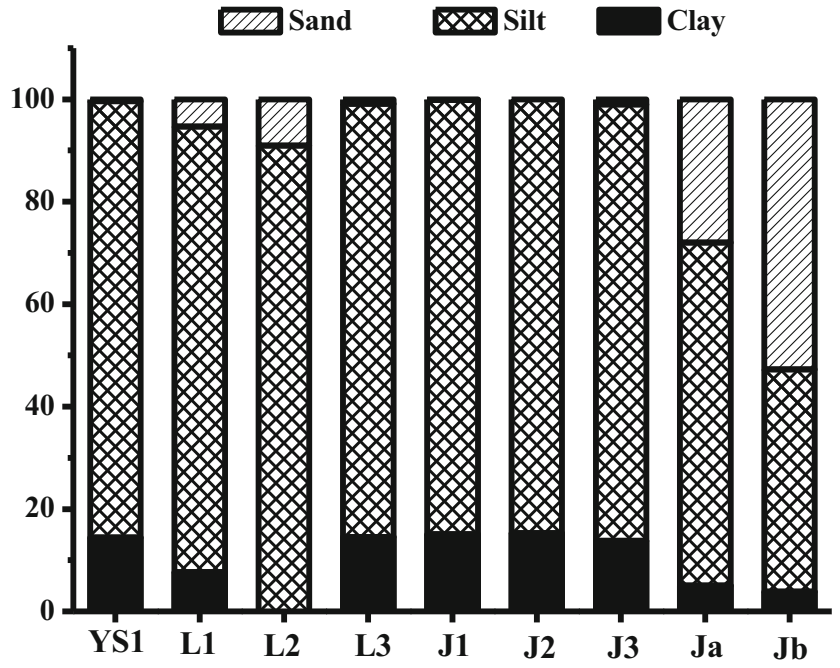

Fig. 2 Grain size distributions of the nine representative sediment samples optimal $\mathrm{pH}$ range for TP measurement is $3-5.5$ (weak acid conditions). The low concentration of TP at high $\mathrm{pH}(6.5-$ 12) levels may be due to ascorbic acid being more likely to be oxidized under alkaline conditions.

\subsection{The digestion efficiency of $\mathrm{H}_{2} \mathrm{SO}_{4}+\mathrm{K}_{2} \mathrm{~S}_{2} \mathrm{O}_{8}$ and $\mathrm{NaOH}+\mathrm{K}_{2} \mathrm{~S}_{2} \mathrm{O}_{8}$}

Figure 4 shows that the TP digestion efficiency with $\mathrm{H}_{2} \mathrm{SO}_{4}+$ $\mathrm{K}_{2} \mathrm{~S}_{2} \mathrm{O}_{8}$ is relatively higher than with $\mathrm{NaOH}+\mathrm{K}_{2} \mathrm{~S}_{2} \mathrm{O}_{8}$. For group F, the background concentration of IP is $70.8 \mathrm{mg} \mathrm{kg}^{-1}$ in the sediment. For groups $\mathrm{A}-\mathrm{C}$, the TP digestion efficiency is not promoted with amounts of $2.5 \mathrm{~mol} \mathrm{~L}^{-1} \mathrm{NaOH}$ lower than $2 \mathrm{~mL}(3<\mathrm{pH}<5)$ compared to group G. However, the TP digestion efficiency increases as the amount of $\mathrm{NaOH}$ increases (groups D and $\mathrm{E}$ ). This finding is because the thermal decomposition of persulfate was promoted by $\mathrm{OH}^{-}\left(\mathrm{H}^{+}\right.$ can be neutralized by $\mathrm{OH}^{-}$), which can enhance $\mathrm{O}_{2} \cdot$ with strong oxidizing properties (Halstead et al. 1999).

$\mathrm{S}_{2} \mathrm{O}_{8}{ }^{2-}+\mathrm{H}_{2} \mathrm{O} \rightarrow 2 \mathrm{SO}_{4}{ }^{2-}+1 / 2 \mathrm{O}_{2}+2 \mathrm{H}^{+} ;$

$\mathrm{OH}^{-}+\mathrm{H}^{+} \rightarrow \mathrm{H}_{2} \mathrm{O}$

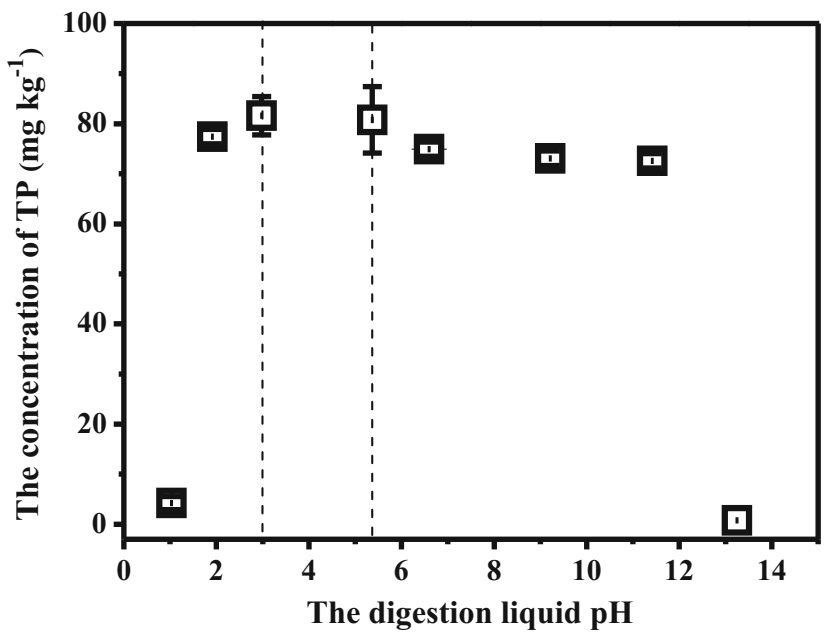

Fig. 3 The influence of different digestion liquids $\mathrm{pH}$ on the determination of TP 


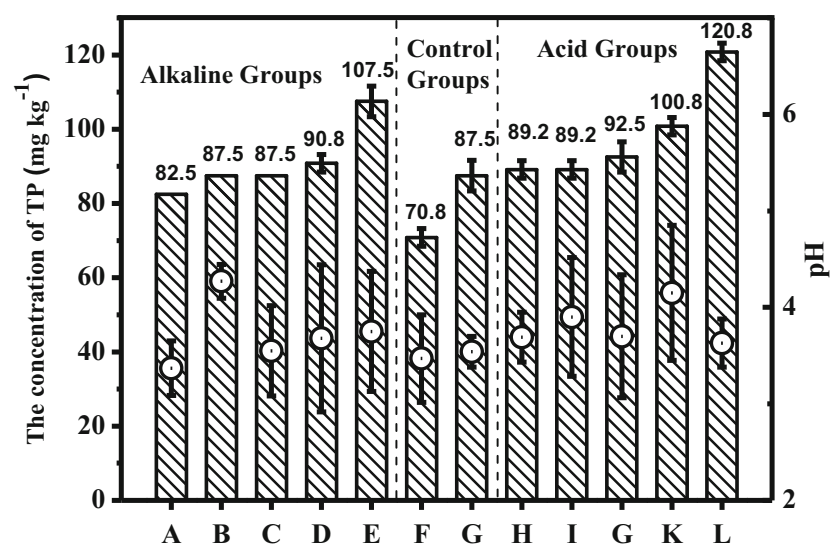

Fig. 4 The TP digestion efficiency was under the alkaline, the acid peroxydisulfate, and the standard method digestive conditions (left). All of the $\mathrm{pH}$ in the digestion of each group was adjusted to the optimal interval (3-5.5) prior to effective TP measurement (right)

For groups $\mathrm{H}-\mathrm{L}$, the $\mathrm{OP}$ digestion efficiency was promoted with $2.5 \mathrm{~mol} \mathrm{~L}^{-1} \mathrm{H}_{2} \mathrm{SO}_{4}$, and the efficiency of promotion was higher than the groups with added $\mathrm{NaOH}$. This result was due to the following two reactions ((Eqs. (3) and (4)) (Fuller et al. 2016)

$$
\begin{aligned}
& \mathrm{S}_{2} \mathrm{O}_{8}{ }^{2-}+2 \mathrm{H}_{2} \mathrm{SO}_{4} \rightarrow \mathrm{H}_{2} \mathrm{~S}_{2} \mathrm{O}_{8}+2 \mathrm{HSO}_{4}{ }^{-} \cdot \mathrm{SO}_{4}{ }^{-} ; \\
& \mathrm{S}_{2} \mathrm{O}_{8}{ }^{2-}+\mathrm{H}_{2} \mathrm{O} \rightarrow 2 \mathrm{SO}_{4}{ }^{2-}+1 / 2 \mathrm{O}_{2}{ }^{-}+2 \mathrm{H}^{+}
\end{aligned}
$$

Because $\mathrm{SO}_{4}{ }^{-} \cdot$ and $\mathrm{O}_{2} \cdot$ are strong oxidizing radicals, the $\mathrm{OP}$ digestion efficiency of $\mathrm{H}_{2} \mathrm{SO}_{4}+\mathrm{K}_{2} \mathrm{~S}_{2} \mathrm{O}_{8}$ is higher than that of $\mathrm{NaOH}+\mathrm{K}_{2} \mathrm{~S}_{2} \mathrm{O}_{8}$. Additionally, the $\mathrm{pH}$ of the digestion solution in all groups $(\mathrm{A}-\mathrm{L})$ was adjusted to the optimal $\mathrm{pH}$ range after digestion and prior to effective TP measurement $(3<\mathrm{pH}$ $<5.5$ ) as shown in Fig. 4.

Based on these results, the digestion system of $\mathrm{H}_{2} \mathrm{SO}_{4}+$ $\mathrm{K}_{2} \mathrm{~S}_{2} \mathrm{O}_{8}$ is more effective than $\mathrm{NaOH}+\mathrm{K}_{2} \mathrm{~S}_{2} \mathrm{O}_{8}$ for determining TP in a sediment extraction. However, both the alkaline and the acid peroxydisulfate can be recommended for TP determination rather than the Chinese EPA standard method (group G).

For TN determination, the digestion efficiency of $\mathrm{NaOH}+$ $\mathrm{K}_{2} \mathrm{~S}_{2} \mathrm{O}_{8}$ is significantly higher than that of $\mathrm{H}_{2} \mathrm{SO}_{4}+\mathrm{K}_{2} \mathrm{~S}_{2} \mathrm{O}_{8}$ (Fig. 5a). For groups 1-5, the TN digestion efficiency is similar to group 7. This result suggests that the alkaline $\mathrm{K}_{2} \mathrm{~S}_{2} \mathrm{O}_{8}$ digestion method for $\mathrm{TN}$ is a stable and reliable. In addition, $\mathrm{NH}_{4}{ }^{+}$is more easily oxidized with increasing $\mathrm{pH}$, so $\mathrm{NH}_{3(\mathrm{aq})}$ is more easily oxidized than $\mathrm{NH}_{4}{ }^{+}$. If there is excessive addition of $\mathrm{NaOH}, \mathrm{NH}_{4}{ }^{+}$could be hydrolyzed into $\mathrm{NH}_{3} \cdot \mathrm{H}_{2} \mathrm{O}$, which could be oxidized to $\mathrm{N}_{2}$ by $\mathrm{S}_{2} \mathrm{O}_{8}{ }^{2-}$ (Ball et al. 1985) (Eq. (5)). Therefore, TN digestion efficiency began to decrease in group 5.

$$
3 \mathrm{~S}_{2} \mathrm{O}_{8}{ }^{2-}+2 \mathrm{NH}_{3(\mathrm{aq})} \rightarrow \mathrm{N}_{2}+6 \mathrm{H}^{+}+6 \mathrm{SO}_{4}{ }^{2-}
$$
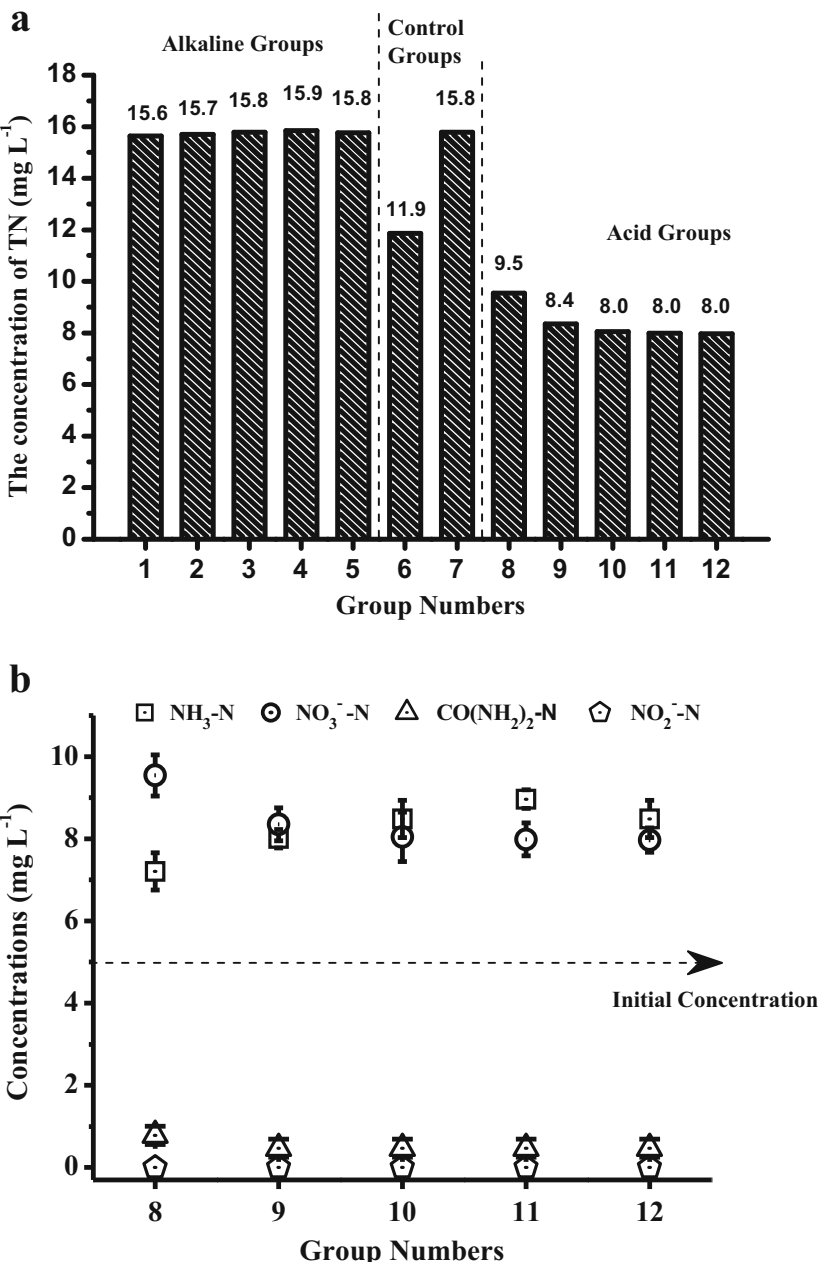

Fig. 5 The TN digestion efficiency was under the alkaline, acid peroxydisulfate, and the standard method digestive conditions (a). The concentrations of different forms of $\mathrm{N}$ in the acid group tubes after digestion (b). The dotted arrow represent the initial spiked three forms $\mathrm{N}\left(\mathrm{NO}_{3}{ }^{-}-\mathrm{N}, \mathrm{CO}\left(\mathrm{NH}_{2}\right)_{2}-\mathrm{N}\right.$, and $\left.\mathrm{NH}_{3}-\mathrm{N}\right)$ concentrations in the standard artificial solution before digestion

In groups $8-12$, the $\mathrm{TN}$ digestion efficiency was suppressed with $\mathrm{H}_{2} \mathrm{SO}_{4}$, and the efficiency decreased as $\mathrm{H}_{2} \mathrm{SO}_{4}$ increased. Different forms of $\mathrm{N}$ were measured in the five acidic groups (Fig. 5b). The amounts of $\mathrm{NH}_{3}-\mathrm{N}$ first increased and then decreased as the amounts of $\mathrm{H}_{2} \mathrm{SO}_{4}$ increased (from 7.2 to 8.9 and finally to $8.5 \mathrm{mg} \mathrm{L}^{-1}$ ). However, the concentrations of urea- $\mathrm{N}\left(\mathrm{CO}\left(\mathrm{NH}_{2}\right)_{2}-\mathrm{N}\right)$ in the acidic groups decreased as $\mathrm{H}_{2} \mathrm{SO}_{4}$ increased (from 0.78 to $0.47 \mathrm{mg} \mathrm{L}^{-1}$ ), and nitrite- $\mathrm{N}$ $\left(\mathrm{NO}_{2}^{-}-\mathrm{N}\right)$ was not detected in the acidic groups.

The concentrations of $\mathrm{NH}_{3}-\mathrm{N}, \mathrm{CO}\left(\mathrm{NH}_{2}\right)_{2}-\mathrm{N}$, and $\mathrm{NO}_{2}{ }^{-} \mathrm{N}$ were $5 \mathrm{mg} \mathrm{L}^{-1}$ in the original standard artificial solutions. After the digestion, $\mathrm{NH}_{3}-\mathrm{N}$ increased, but $\mathrm{CO}\left(\mathrm{NH}_{2}\right)_{2}-\mathrm{N}$ decreased to nearly $0 \mathrm{mg} \mathrm{L}^{-1}$ in the acidic groups. Previous studies suggested that it is difficult to oxidize $\mathrm{NH}_{3}-\mathrm{N}$ under acidic conditions (Nakamura et al. 2014). The primary decomposition products of urea are $\mathrm{NH}_{3}$ and $\mathrm{HNCO}$ (Eq. (6)). However, there is no 
Table 3 Disposition and result of orthogonal experimental design L16 $\left(4^{3}\right)$

\begin{tabular}{llllllll}
\hline Number & $\mathrm{A}$ & $\mathrm{B}$ & $\mathrm{C}$ & $\mathrm{TP} 1\left(\mathrm{mg} \mathrm{kg}^{-1}\right)$ & $\mathrm{TP} 2\left(\mathrm{mg} \mathrm{kg}^{-1}\right)$ & $\mathrm{TP} 3\left(\mathrm{mg} \mathrm{kg}^{-1}\right)$ & $\mathrm{TP} 4\left(\mathrm{mg} \mathrm{kg}^{-1}\right)$ \\
\hline 1 & 2 & 3 & 5 & 3.63 & 14.73 & 3.93 & 2.43 \\
2 & $5^{\mathbf{c}}$ & 5 & 5 & 8.73 & 30.43 & 9.73 & 5.83 \\
3 & 1 & 2 & 5 & 1.93 & 8.23 & 2.03 & 1.53 \\
4 & $5^{\mathbf{c}}$ & 2 & 3 & 8.83 & 30.23 & 9.53 & 5.93 \\
5 & 2 & 2 & 2 & 3.63 & 15.73 & 4.03 & 2.73 \\
6 & $5^{\mathrm{c}}$ & 1 & 2 & 8.43 & 30.23 & 9.53 & 6.13 \\
7 & 3 & 3 & 3 & 5.53 & 22.83 & 6.03 & 3.83 \\
8 & 3 & 2 & 1 & 5.33 & 23.13 & 6.03 & 3.83 \\
9 & 1 & 1 & 1 & 1.93 & 8.13 & 2.13 & 1.43 \\
10 & 2 & 5 & 1 & 3.93 & 15.13 & 4.03 & 2.83 \\
11 & 1 & 3 & 2 & 1.93 & 8.13 & 2.43 & 1.43 \\
12 & 3 & 5 & 2 & 5.63 & 22.33 & 5.83 & 2.83 \\
13 & 2 & 1 & 3 & 3.53 & 15.13 & 4.23 & 1.93 \\
14 & 1 & 5 & 3 & 2.23 & 8.33 & 2.33 & 6.33 \\
15 & $5^{\mathbf{c}}$ & 3 & 1 & 8.83 & 30.03 & 10.03 & 4.43 \\
16 & 3 & 1 & 5 & 5.33 & 23.23 & 6.33 & \\
\hline
\end{tabular}

${ }^{\mathrm{c}}$ The moderately labile OP extracting solution $(1 \mathrm{M} \mathrm{HCl}, 3 \mathrm{~h})$ was $4 \mathrm{~mL}$ consensus as to whether $\mathrm{HNCO}$ is produced or not (Alzueta et al. 1998). Therefore, $\mathrm{CO}\left(\mathrm{NH}_{2}\right)_{2}-\mathrm{N}$ was decomposed to $\mathrm{NH}_{3}-$ $\mathrm{N}$ and "X-N," thereby increasing the amount of $\mathrm{NH}_{3}-\mathrm{N}$ in the solution. Then, the $\mathrm{X}-\mathrm{N}$ was oxidized to $\mathrm{NO}_{3}{ }^{-}-\mathrm{N}$, increasing the content of $\mathrm{NO}_{3}{ }^{-}-\mathrm{N}$. The original $\mathrm{NH}_{3}-\mathrm{N}$ in the acid tubes was not oxidized during the digestion. Finally, all forms of $\mathrm{N}$ added up to $\sim 15 \mathrm{mg} \mathrm{L}^{-1}$ in each tube after digestion, observing the $\mathrm{N}$ conservation law. Hence, the mechanisms of digestion for $\mathrm{NH}_{3}-\mathrm{N}, \mathrm{CO}\left(\mathrm{NH}_{2}\right)_{2}-\mathrm{N}$, and $\mathrm{NO}_{3}{ }^{-}-\mathrm{N}$ are most likely the following reactions (Eqs. (7) and (8)):

$$
\begin{aligned}
& \mathrm{H}_{2} \mathrm{~N}-\mathrm{CO}-\mathrm{NH}_{2} \rightarrow \mathrm{NH}_{3}+\mathrm{HNCO} \\
& \mathrm{H}_{2} \mathrm{~N}-\mathrm{CO}-\mathrm{NH}_{2} \rightarrow \mathrm{NH}_{3}+\mathrm{X}-\mathrm{N} \\
& \mathrm{X}-\mathrm{N} \rightarrow \mathrm{NO}_{3}{ }^{-}-\mathrm{N}
\end{aligned}
$$

Based on these results, the digestion system of $\mathrm{H}_{2} \mathrm{SO}_{4}+$ $\mathrm{K}_{2} \mathrm{~S}_{2} \mathrm{O}_{8}$ should not be selected for TN measurement. The alkaline $\mathrm{K}_{2} \mathrm{~S}_{2} \mathrm{O}_{8}$ method can be selected over the Chinese
EPA standard method (group G for TP and group 7 for TN) for simultaneous determination of $\mathrm{TP}$ and $\mathrm{TN}$, under certain conditions (Worsfold et al. 2005). However, understanding what types of oxidation agents or conditions could convert $\mathrm{NH}_{3}-\mathrm{N}$ to $\mathrm{NO}_{3}{ }^{-}-\mathrm{N}$ directly (no $\mathrm{N}_{2}$ production) in strong acid conditions and understanding whether there are other digestion agents that could simultaneously oxidize all forms of $\mathrm{P}$ to IP (for TP determination) and all forms of $\mathrm{N}$ to $\mathrm{NO}_{3}{ }^{-} \mathrm{N}$ (for TN measurement) remains to be discovered.

\subsection{The orthogonal experiment of OP digestion efficiency}

Based on the results, the orthogonal experiment L16 $\left(4^{3}\right)$ of OP was designed to investigate the impact of the amount of $\mathrm{OP}, \mathrm{H}_{2} \mathrm{SO}_{4}$, and $\mathrm{K}_{2} \mathrm{~S}_{2} \mathrm{O}_{8}$ on the OP digestion efficiency (Table 3). The values of TP1, TP2, TP3, and TP4 represent the $\mathrm{P}$ concentrations in four kinds of OP extracting solutions

\begin{tabular}{|c|c|c|c|c|c|c|c|c|c|c|c|c|}
\hline \multirow[t]{2}{*}{ Number } & \multicolumn{3}{|c|}{$\mathrm{TP} 1\left(\mathrm{mg} \mathrm{kg}^{-1}\right)$} & \multicolumn{3}{|c|}{$\mathrm{TP} 2\left(\mathrm{mg} \mathrm{kg}^{-1}\right)$} & \multicolumn{3}{|c|}{ TP3 $\left(\mathrm{mg} \mathrm{kg}^{-1}\right)$} & \multicolumn{3}{|c|}{$\mathrm{TP} 4\left(\mathrm{mg} \mathrm{kg}^{-1}\right)$} \\
\hline & A & $\mathrm{B}$ & $\mathrm{C}$ & A & $\mathrm{B}$ & $\mathrm{C}$ & $\mathrm{A}$ & $\mathrm{B}$ & $\mathrm{C}$ & $\mathrm{A}$ & $\mathrm{B}$ & $\mathrm{C}$ \\
\hline $\mathrm{K} 1$ & 2.01 & 1.79 & 1.68 & 8.21 & 7.75 & 7.73 & 2.23 & 2.07 & 2.04 & 1.75 & 1.53 & 1.49 \\
\hline $\mathrm{K} 2$ & 1.84 & 1.64 & 1.83 & 7.59 & 7.84 & 7.75 & 2.03 & 1.99 & 2.07 & 1.49 & 1.48 & 1.45 \\
\hline K3 & 1.64 & 1.84 & 1.90 & 7.63 & 7.65 & 7.77 & 2.02 & 2.10 & 2.09 & 1.46 & 1.43 & 1.60 \\
\hline K4 & 1.74 & 1.95 & 1.82 & 7.56 & 7.74 & 7.74 & 1.94 & 2.06 & 2.01 & 1.34 & 1.59 & 1.49 \\
\hline $\mathrm{R}$ & 0.37 & 0.31 & 0.22 & 0.65 & 0.19 & 0.04 & 0.29 & 0.11 & 0.08 & 0.41 & 0.16 & 0.15 \\
\hline Order & \multicolumn{3}{|c|}{$\mathrm{A}>\mathrm{B}>\mathrm{C}$} & \multicolumn{3}{|c|}{$\mathrm{A}>\mathrm{B}>\mathrm{C}$} & \multicolumn{3}{|c|}{$\mathrm{A}>\mathrm{B}>\mathrm{C}$} & \multicolumn{3}{|c|}{$\mathrm{A}>\mathrm{B}>\mathrm{C}$} \\
\hline Results & \multicolumn{3}{|c|}{ A1B4C3 } & \multicolumn{3}{|c|}{ A1B2C3 } & \multicolumn{3}{|c|}{$\mathrm{A} 1 \mathrm{~B} 3 \mathrm{C} 3$} & \multicolumn{3}{|c|}{ A1B4C3 } \\
\hline
\end{tabular}

Table 4 The result of orthogonal polar difference analysis 
Table 5 Concentrations and the recovery of different OP fractions in the sediments

\begin{tabular}{|c|c|c|c|c|c|c|c|c|}
\hline \multirow{2}{*}{ Sediments } & \multirow{2}{*}{$\begin{array}{l}\text { Labile OP } \\
\mathrm{NaHCO}_{3^{-}} \\
\mathrm{OP}\left(\mathrm{mg} \mathrm{kg}^{-1}\right)\end{array}$} & \multicolumn{2}{|c|}{ Moderately labile OP } & \multicolumn{2}{|l|}{ Nonlabile OP } & \multirow{2}{*}{$\begin{array}{l}\text { Total extracted } \\
\text { OP }\left(\mathrm{mg} \mathrm{kg}^{-1}\right)\end{array}$} & \multirow{2}{*}{$\begin{array}{l}\text { Total OP } \\
\left(\mathrm{mg} \mathrm{kg}^{-1}\right)\end{array}$} & \multirow{2}{*}{$\begin{array}{l}\text { Recovery } \\
(\%)\end{array}$} \\
\hline & & $\begin{array}{l}\mathrm{HCl}-\mathrm{OP} \\
\left(\mathrm{mg} \mathrm{kg}^{-1}\right)\end{array}$ & $\begin{array}{l}\text { Fulvic acid-OP } \\
\left(\mathrm{mg} \mathrm{kg}^{-1}\right)\end{array}$ & $\begin{array}{l}\text { Humic acid-OP } \\
\left(\mathrm{mg} \mathrm{kg}^{-1}\right)\end{array}$ & $\begin{array}{l}\text { Residual- } \\
\text { OP }\left(\mathrm{mg} \mathrm{kg}^{-1}\right)\end{array}$ & & & \\
\hline YS1 & 12.5 & 5 & 25.5 & 0.7 & 42.5 & 86.2 & 92 & 93.7 \\
\hline L1 & 15 & 5 & 8.7 & 2.5 & 17.5 & 48.7 & 48 & 101.5 \\
\hline L2 & 2.5 & 2.5 & 2.75 & 0 & 17.5 & 25.25 & 26 & 97.1 \\
\hline L3 & 35.8 & 40 & 55 & 46.5 & 74.2 & 251.5 & 250 & 100.6 \\
\hline $\mathrm{J} 1$ & 12.5 & 17.5 & 24.1 & 14.3 & 32.5 & 100.9 & 110 & 91.7 \\
\hline $\mathrm{J} 2$ & 12.5 & 5 & 22.2 & 9.9 & 37.5 & 87.1 & 85 & 102.5 \\
\hline $\mathrm{J} 3$ & 42.5 & 20 & 44.3 & 50.1 & 27.5 & 184.4 & 189 & 97.6 \\
\hline $\mathrm{Ja}$ & 17.5 & 15 & 25 & 40 & 94.5 & 192 & 190 & 101.1 \\
\hline $\mathrm{Jb}$ & 50 & 55 & 97.5 & 112.5 & 83.7 & 398.7 & 380 & 102.2 \\
\hline
\end{tabular}

$\left(0.5 \mathrm{~mol} \mathrm{~L}^{-1} \mathrm{NaHCO}_{3}, 16 \mathrm{~h} ; 1 \mathrm{~mol} \mathrm{~L}^{-1} \mathrm{HCl}, 3 \mathrm{~h} ; 0.5 \mathrm{~mol} \mathrm{~L}^{-1}\right.$ $\mathrm{NaOH}, 16 \mathrm{~h} ; \mathrm{HCl}$ added into $0.5 \mathrm{~mol} \mathrm{~L}^{-1} \mathrm{NaOH}$ extraction to adjust, $\mathrm{pH}=0.2$ ) after digestion.

According to the results of the orthogonal polar difference analysis, the order of influence of the factors is A > B > C (Table 4). Therefore, the amount of $\mathrm{P}$ is the major factor that influences the digestion efficiency, followed by $\mathrm{H}_{2} \mathrm{SO}_{4}$ and $\mathrm{K}_{2} \mathrm{~S}_{2} \mathrm{O}_{8}$. The optimal combinations of the extracting solution for $\mathrm{P}$ by $\mathrm{NaHCO}_{3}, \mathrm{HCl}, \mathrm{NaOH}$, and $\mathrm{NaOH}(\mathrm{pH}=0.2)$ are $\mathrm{A} 1 \mathrm{~B} 4 \mathrm{C} 3, \mathrm{~A} 1 \mathrm{~B} 2 \mathrm{C} 3, \mathrm{~A} 1 \mathrm{~B} 3 \mathrm{C} 3$, and $\mathrm{A} 1 \mathrm{~B} 4 \mathrm{C} 3$, respectively. After calculating the optimal combinations, the mass ratios of $\mathrm{P}, \mathrm{K}_{2} \mathrm{~S}_{2} \mathrm{O}_{8}$, and $\mathrm{H}_{2} \mathrm{SO}_{4}$, respectively, are $\sim 1.5 \times 10^{-5}: 1: 8$ $\left(\mathrm{NaHCO}_{3}, 16 \mathrm{~h}\right), \sim 5.6 \times 10^{-5}: 1: 3(\mathrm{HCl}, 3 \mathrm{~h}), \sim 1.6 \times$ $10^{-5}: 1: 5(\mathrm{NaOH}, 16 \mathrm{~h})$, and $\sim 1.4 \times 10^{-5}: 1: 8(\mathrm{NaOH}, 16 \mathrm{~h}$, $\mathrm{pH}=0.2$ ). The digestion solution $\mathrm{pH}$ values were adjusted to the optimal $\mathrm{pH}$ range prior to analysis $(\mathrm{pH} 3-5.5)$.

Nine types of sediments from different sampling areas (Fig. 1) were analyzed to determine the OP concentrations under the established optimal conditions. The recovery (\%) of OP was measured as the ratio of total extracted OP to TOP (Zhang et al. 2008). Table 5 shows that the recoveries were $92-103 \%$. There is high recovery and reproducibility when using the optimized method.

\section{Conclusions}

A method of digesting OP in sediments using a sequential extraction based on the Ivanoff method was optimized in this study. The $\mathrm{pH}$ of solutions after digestion affects the color development necessary for effective $\mathrm{P}$ determination. The optimal $\mathrm{pH}$ for digestion ranges from 3 to 5.5. Additionally, the OP digestion efficiency using $\mathrm{H}_{2} \mathrm{SO}_{4}+\mathrm{K}_{2} \mathrm{~S}_{2} \mathrm{O}_{8}$ is, on average, $8 \%$ higher than that of $\mathrm{NaOH}+\mathrm{K}_{2} \mathrm{~S}_{2} \mathrm{O}_{8}$. The alkaline $\mathrm{K}_{2} \mathrm{~S}_{2} \mathrm{O}_{8}$ digestion method can be selected for simultaneous determination of TP and TN, under certain conditions. Finally, the optimal orthogonal combinations and the mass ratios of $\mathrm{P}, \mathrm{K}_{2} \mathrm{~S}_{2} \mathrm{O}_{8}$, and $\mathrm{H}_{2} \mathrm{SO}_{4}$, respectively, are $\sim 1.5 \times 10^{-5}: 1: 8\left(\mathrm{NaHCO}_{3}, 16 \mathrm{~h}\right), \sim 5.6 \times$ $10^{-5}: 1: 3(\mathrm{HCl}, 3 \mathrm{~h}), \sim 1.6 \times 10^{-5}: 1: 5(\mathrm{NaOH}, 16 \mathrm{~h})$, and $\sim$ $1.4 \times 10^{-5}: 1: 8(\mathrm{NaOH}, 16 \mathrm{~h}, \mathrm{pH}=0.2)$. The accuracy and precision of the optimized Ivanoff method are improved in the present study.

Funding information This study was supported by the National Natural Science Foundation of China (Grant No. 41373100). Additional support was provided by the Science and Technology Program for Public Wellbeing of Shandong Province (Grant No. 2013kjhm060308) and the CAS Key Technology Talent Program.

\section{References}

Aspila KI, Agemian H, Chau ASY (1976) Semiautomated method for determination of inorganic, organic and total phosphate in sediments. Analyst 101:187-197

Alzueta MU, Bilbao R, Millera A, Oliva M, Ibanez JC (1998) Interactions between nitric oxide and urea under flow reactor conditions. Energy Fuel 12:1001-1007

Ahlgren J, Tranvik L, Gogoll A, Waldeback M, Markides K, Rydin E (2005) Sediment depth attenuation of biogenic phosphorus compounds measured by ${ }^{31} \mathrm{P}$ NMR. Environ Sci Technol 39:867-872

Bowman RA, Cole CV (1978) Exploratory method for fractionation of organic phosphorus from grassland soils. Soil Sci 125:95-101

Ball RE, Chako A, Edwards JO, Levey G (1985) Mechanisms of oxidation of nitrogen nucleophiles by peroxodisulfate ion: nitrite ion and ammonia. Inorganica Chimica Acta-Articles and Letters 99:49-58

Bostrom B, Pettersson AK, Ahlgren I (1989) Seasonal dynamics of a cyanobacteria-dominated microbial community in surface sediments of a shallow, eutrophic lake. Aquat Sci 51:153-178

Bowman RA (1989) A sequential extraction procedure with concentrated sulfuric acid and dilute base for soil organic phosphorus. Soil Sci SocAmJ 53:362-366

Bi SJ, Zhao XF (2017) 40Ar/39Ar dating of the Jiehe gold deposit in the Jiaodong Peninsula, eastern North China Craton: implications for regional gold metallogeny. Ore Geol Reviews 86:639-651

Chinese EPA (2002) Methods for the examination of water and wastewater, 4th edn. Environmental Science Press, Beijing 
Cai Y, Mi Y, Yu J, Zhang H (2015) Arsenic speciation and kinetic release simulation of stream sediment contaminated by gold mining. J Soils Sediments 16:1121-1129

Chowdhury RB, Moore GA, Weatherley AJ, Arora M (2017) Key sustainability challenges for the global phosphorus resource, their implications for global food security, and options for mitigation. J Clean Prod 140:945-963

Dodds WK, Bouska WW, Eitzmann JL, Pilger TJ, Pitts KL, Riley AJ, Schloesser JT, Thornbrugh DJ (2009) Eutrophication of US freshwaters: analysis of potential economic damages. Environ Sci Technol 43:12-19

Ding SM, Bai XL, Fan CX, Zhang L (2010) Caution needed in pretreatment of sediments for refining phosphorus-31 nuclear magnetic resonance analysis: results from a comprehensive assessment of pretreatment with ethylenediaminetetraacetic acid. J Environ Qual 39: $1668-1678$

Fuller JT, Butler S, Devarajan D, Jacobs A, Hashiguchi BG, Konnick MM, Goddard WA, Gonzales J, Periana RA, Ess DH (2016) Catalytic mechanism and efficiency of methane oxidation by $\mathrm{Hg}(\mathrm{II})$ in sulfuric acid and comparison to radical initiated conditions. ACS Catal 6:4312-4322

Fowdar HS, Hatt BE, Cresswell T, Harrison JJ, Cook PLM, Deletic A (2017) Phosphorus fate and dynamics in greywater biofiltration systems. Environ Sci Technol 51:2280-2287

Golterman H, Paing J, Serrano L, Gomez E (1998) Presence of and phosphate release from polyphosphates or phytate phosphate in lake sediments. Hydrobiologia 364:99-104

Hieltjes AHM, Lijklema L (1980) Fractionation of inorganic phosphates in calcareous sediments. J Environ Qual 9:405-407

Halstead JA, Edwards J, Soracco RJ, Armstrong RW (1999) Potential for chlorate interference in ion chromatographic determination of total nitrogen in natural waters following alkaline persulfate digestion. JChromatogrA 857:337-342

Hu K, Pang Y, Wang H, Wang X, Wu X, Bao K, Liu Q (2011) Simulation study on water quality based on sediment release flume experiment in Lake Taihu, China. Ecol Eng 37:607-615

Hou X, Huang X, Ai Z, Zhao J, Zhang L (2017) Ascorbic acid induced atrazine degradation. J Hazard Mater 327:71-78

Ivanoff DB, Reddy KR, Robinson S (1998) Chemical fractionation of organic phosphorus in selected histosols. Soil Sci 163:36-45

Jafarabadi AR, Bakhtiari AR, Aliabadian M, Toosi AS (2017) Spatial distribution and composition of aliphatic hydrocarbons, polycyclic aromatic hydrocarbons and hopanes in superficial sediments of the coral reefs of the Persian Gulf, Iran. Environ Pollut 224:195-223

Kaiserli A, Voutsa D, Samara C (2002) Phosphorus fractionation in lake sediments-lakes Volvi and Koronia, N. Greece. Chemosphere 46: $1147-1155$

Li M, Zhang J, Wang G, Yang H, Whelan MJ, White SM (2013) Organic phosphorus fractionation in wetland soil profiles by chemical extraction and phosphorus-31 nuclear magnetic resonance spectroscopy. Appl Geochem 33:213-221

Li J, Lin S, Qin S (2016) Characteristics of sediment bacterial community in response to environmental impacts in a sewage polluted river. J Coastal Res 74:196-206

Murphy J, Riley JP (1962) A modified single solution method for the determination of phosphate in nature waters. Anal Chim Acta 27:7
Mowry S, Ogren PJ (1999) Kinetics of methylene blue reduction by ascorbic acid. J Chem Educ 76:970-974

Monbet P, McKelvieIan D, WorsfoldPaul J (2007) Phosphorus speciation, burial and regeneration in coastal lagoon sediments of the Gippsland Lakes (Victoria, Australia). Environ Chem 4:334-346

Nakamura T, Uchida R, Kubota M, Matsuda H, Fukuta T (2014) Comparative studies of wet oxidation of ammonium compounds using persulfate at temperatures of 313-343 K under ambient air pressure. Chem Eng J 250:205-213

Oluyedun OA, Ajayi SO, Vanloon GW (1991) Methods for fractionation of organic phosphorus in sediments. Sci Total Environ 106:243-252

Pandurangappa M, Venkataramanappa Y (2007) Aminophenyl benzimidazole as a new reagent for the estimation of $\mathrm{NO}_{2} /$ nitrite/nitrate at trace level: application to environmental samples. Anal Lett 40: 2974-2991

Sharpley AN, Smith SJ (1985) Fractionation of inorganic and organic phosphorus in virgin and cultivated soils. Soil Sci Soc Am J 49: $127-130$

Suzumura M, Kamatani A (1995) Mineralization of inositol hexaphosphate in aerobic and anaerobic marine sediments: implications for the phosphorus cycle. Geochim Cosmochim Acta 59: $1021-1026$

Snehalatha T, Rajanna KC, Saiprakash PK (1997) Methylene blueascorbic acid: an undergraduate experiment in kinetics. J Chem Educ 74:228

Smi V (2000) Phosphorus in the environment: natural flows and human interferences. Ann Rev Energ Environ 25:53-88

Slomp CP, Thomson J, de Lange GJ (2002) Enhanced regeneration of phosphorus during formation of the most recent eastern Mediterranean sapropel (S1). Geochim Cosmochim Acta 66:1171-1184

Tiessen H, Stewart JWB, Moir JO (1983) Changes in organic and inorganic phosphorus composition of 2 grassland soils and their particle size fractions during 60-90 years of cultivation. J Soil Sci 34:815-823

Turner BL, Paphazy MJ, Haygarth PM, McKelvie ID (2002) Inositol phosphates in the environment. Philos Trans R Soc Lond Ser B Biol Sci 357:449-469

Worsfold PJ, Gimbert LJ, Mankasingh U, Omaka ON, Hanrahan G (2005) Sampling, sample treatment and quality assurance issues for the determination of phosphorus species in natural waters and soils. Talanta 66:273-293

Waterlot C (2018) Alternative approach to the standard, measurements and testing programme used to establish phosphorus fractionation in soils. Anal Chim Acta 1003:26-33

Zhang R, Wu F, Liu C, Fu P, Li W, Wang L, Liao H, Guo J (2008) Characteristics of organic phosphorus fractions in different trophic sediments of lakes from the middle and lower reaches of Yangtze River region and Southwestern Plateau, China. Environ Pollut 152: 366-372

Zhao LJ, Yan J, Ma DS, Fan ZY, Xiao JZ, Zhao P (2011) Determination of urea in milk and milk products by in-line dialysis-flow injectionspectrophotometry. Chin J Anal Chem 39:183-187

Zhou Y, Wang S, Chen S (2012) Key factors on the accuracy of total nitrogen analysis. Environ Eng 30:106-110

Zhu Y, Wu F, He Z, Guo J, Qu X, Xie F, Giesy JP, Liao H, Guo F (2013) Characterization of organic phosphorus in lake sediments by sequential fractionation and enzymatic hydrolysis. Environ Sci Technol 47:7679-7687 